\title{
IMPACT OF IN SITU RICE CROP RESIDUE BURNING ON AGRICULTURAL SOIL OF DISTRICT BATHINDA, PUNJAB, INDIA
}

\author{
Roopjit Kaur $^{1, *}$, Manjeet Bansal ${ }^{2}$, Seema Sharma ${ }^{3}$ and Sridevi Tallapragada ${ }^{4}$ \\ ${ }^{1}$ Junior Research Fellow, Biotechnology, I. K. Gujral Punjab Technical University, \\ Jalandhar- 144603, Punjab, India \\ ${ }^{2}$ Department of Civil Engineering, Giani Zail Singh Campus College of Engineering \& \\ Technology, Bathinda-151001, Punjab \\ ${ }^{3}$ Department of Chemistry, Maharaja Ranjit Singh Punjab Technical University, \\ Bathinda-151001, Punjab \\ ${ }^{4}$ WAPCOS Ltd., Water Resources Ministry, GOI, Sector 19, Chandigarh-160019, India \\ *Email: roop.cevs@gmail.com
}

\begin{abstract}
The study was carried out to explore the effect of in situ rice crop residue burning on physicochemical and biological properties of soil. Physico-chemical properties under investigation included soil pH, electrical conductivity, organic matter, total phosphorus, nitrogen and potassium. Result analysis showed an increase in mean $\mathrm{pH}$ and electrical conductivity values of soil samples from 7.94 and $245-699 \mu \mathrm{S} / \mathrm{cm}$ (pre-burning period) to 8.46 and 403-800 $\mu \mathrm{S} / \mathrm{cm}$ (post-burning period). Similarly, a significant increase in soil organic matter for the post-burning period $(27100 \mathrm{mg} / \mathrm{kg}$ ) was observed as compared to the pre-burning period $(25200 \mathrm{mg} / \mathrm{kg})$. However, the nitrogen and phosphorus content decreased significantly in post burning period. The analysis also revealed a significant decrease in enzyme activities of amylase, cellulase, invertase and dehydrogenase in post burning samples. The causes and effects of the changes in physicochemical and biological properties of agriculture soils due to in situ rice crop residue burning have been discussed.
\end{abstract}

Keywords: Rice straw burning, Soil enzyme, Soil property, Macronutrients

(C) RASĀYAN. All rights reserved

\section{INTRODUCTION}

In situ crop residue burning is the burning of residues left in the field after crop harvesting. The residue is mainly stem of the rice plant still anchored with its roots in the soil. Crop residue burning is commonly practiced by farmers in several parts of India to get rid of the crop residue of the previous harvest. Agricultural residues mainly include straw, husks and hulls. Main contributors to biomass burning are wheat residue, maize stalks \& leaves, rice straw \& hulls, barley residue, millet and sorghum stalks. These residues do not have much usage and economic value. The practice is more common in agriculture intensive states like Punjab, Haryana, Rajasthan and Uttar Pradesh.

Crop residue burning is a cheap, convenient, easy and economical method for managing in situ crop residues. Another major reason for the wide acceptance of this practice is the time-saving in clearing the agricultural fields. Often, the farmers have very less time between harvest of one crop and sowing of the next one. However, this management measure has serious environmental and human health implications. The major environmental issues associated with crop residue burning are air pollution, climatic changes and soil pollution. The burning of crop residues also leads to human health problems due to the release of soot particles \& smoke. Air pollution and climate change are due to the emission of greenhouse gases (GHGs) like carbon dioxide, nitrous oxide etc. The in situ crop residue burning adversely affects the soil fertility \& soil properties.

Rasayan J. Chem., 12(2), 421-430(2019)

http://dx.doi.org/10.31788/RJC.2019.1225160

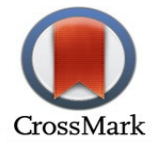


The soil is an important ecological factor since it possesses several peculiar characteristics like the correlation between soil structure \& climate of the region, nature and configuration, and its role in social and economic development of living beings ${ }^{1}$. The burning of agricultural residue leads to significant changes in the physicochemical, biological and biochemical properties of soil ${ }^{2}$. Such changes depend on the intensity and duration of the fire, soil type, moisture and climatic conditions.

The crop residue burning leads to loss of valuable plant nutrients such as sulphur (S), nitrogen (N), phosphorous $(\mathrm{P})$, potassium $(\mathrm{K})$ and wastage of valuable carbon $(\mathrm{C})$ and energy-rich residues ${ }^{4,5}$. Crop residue burning also affects the organic matter content in the soil.

Apart from changes in physicochemical properties and loss of nutrients, it also affects the biochemical properties i.e., activities of soil enzymes ${ }^{6}$. Soil enzymes play a vital role in the catalysis of those reactions that are necessary for organic matter decomposition and cycling of nutrients. Moreover, enzymes are also involved in energy transfer, crop productivity and environmental quality ${ }^{7}$. The soil enzymes are important indicators of soil health in terms of soil friendly microbes, worms, insects etc. The study of hydrolases enzyme is of particular importance due to their close relationship with recycling of important nutrients such as N, P, C and S. Enzymes are present in variable amounts in soil because of certain factors such as organic matter content, microbial activity, soil composition and intensity of biological processes ${ }^{8}$. These enzymes may include amylase, cellulase, chitinase, dehydrogenase, phosphatase, urease, and glucosidase released from microorganisms, animals and plants ${ }^{9}$. Agricultural management practices such as crop rotation, mulching, biomass burning etc. have diverse effects on enzyme activities of soil ${ }^{10}$. Hence, it is necessary to study the impact of crop residue burning on soil properties.

The main purpose of this study is to analyze the impacts of crop residue burning on agricultural soil. For this concern, the physicochemical properties, nutrient dynamics and enzyme activities were studied in soil samples of pre and post-burning periods. The study of enzyme activities would allow a greater understanding of the effects of crop residue burning on soil biological functions. The present study has been carried out in Bathinda district of Punjab, India. Rice and wheat are the major crops grown in the district. The rice is harvested in $3^{\text {rd }}$ or $4^{\text {th }}$ week of October and wheat is sown in $1^{\text {st }}$ or $2^{\text {nd }}$ week of November. This leads to very less time in-between and hence farmers of this district widely practice burning of rice crop residues. No study related to effects of rice crop residue burning on soil nutrient dynamics and soil enzymes of Bathinda district is available. In this regard, soil samples were collected from selected sites of Bathinda district during pre and post rice crop residue burning and studied for physicochemical and enzymatic properties.

\section{Materials and Methods \\ Site and Sampling}

Soil samples were collected during pre and post in situ rice crop residue burning period from agricultural fields of Bathinda district of Punjab, India from 10 sites (Fig.-1) during October \& November 2017. Soil samples were collected in polythene bags with the help of soil auger to a depth of $5-15 \mathrm{~cm}$. A soil sample $(100 \mathrm{~g})$ was taken from each sampling site. The collected samples were sieved and stored at room temperature. For the enzymatic studies, soil samples were stored at $4^{\circ} \mathrm{C}$.

\section{Physicochemical Properties \\ Determination of EC and pH of Soil Samples ${ }^{11,12}$}

A suspension of $30.0 \mathrm{~g}$ of the air-dried soil sample in $60 \mathrm{~mL}$ of double distilled water was taken in a 100 $\mathrm{mL}$ beaker covered by watch glass and stirred for 1 hour on a magnetic stirrer. The suspension was allowed to settle for 10 minutes and EC of the suspension was taken by using a calibrated EC meter. $\mathrm{pH}$ of the suspension was determined by adding $10 \mathrm{~mL}$ more double distilled water in suspension and $\mathrm{pH}$ was taken by a calibrated $\mathrm{pH}$ meter.

\section{Soil organic matter (SOM)}

For the estimation of organic matter, Walkey-Black rapid titration method ${ }^{13}$ was used. $10 \mathrm{~mL} \mathrm{~K}_{2} \mathrm{Cr}_{2} \mathrm{O}_{7}$ $(1 \mathrm{~N})$ and $20 \mathrm{~mL}$ conc. $\mathrm{H}_{2} \mathrm{SO}_{4}$ were added to a dried sample $(1 \mathrm{~g})$ and the mixture was shaken for $3 \mathrm{~h}$. The solution was allowed to stand for $1 \mathrm{~h}$ and $200 \mathrm{~mL}$ of double distilled water was added. 
RASĀYAN J. Chem.

Vol. 12 | No. 2 |421 - 430| April - June | 2019

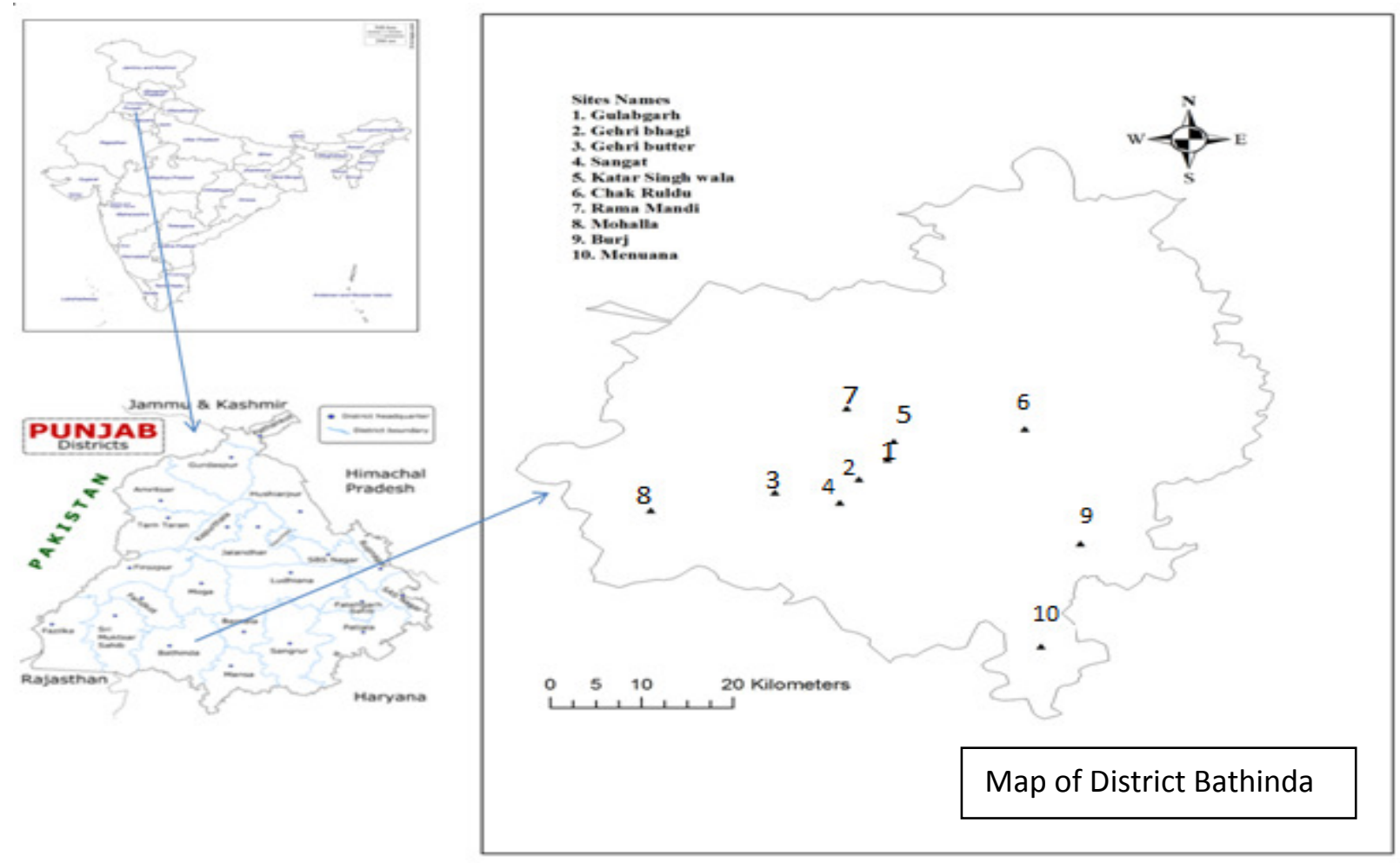

Fig.-1: Soil Sampling Locations for Pre and Post burning Period

This followed the addition of few drops of o-Phenanthroline-ferrous complex indicator. The solution was titrated against $0.5 \mathrm{~N}$ ferrous ammonium sulphate solution. At the end point, the green color solution was sharply changed from blue to red or maroon tinge. The reading was noted and the percent $(\%)$ organic carbon was calculated using the following formula:

$$
\% \text { Organic carbon }=\frac{(\text { Control }- \text { sample }) \times 0.5 \times 0.003 \times 100 \times \text { correction factor }}{\text { weight of soil }}
$$

Correction factor: 1.33 for $1 \mathrm{~g}$ of sample

$$
\% \text { Organic matter }=\% \text { Organic carbon } \times 1.724
$$

\section{Determination of Total $P$ of Soil by using Allen's Method ${ }^{14}$}

A soil sample $(500 \mathrm{mg})$ was mixed in $10 \mathrm{~mL}$ of nitric acid and perchloric acid $(1: 2(\mathrm{v} / \mathrm{v})$. The mixture was digested till the appearance of white fumes. Thereafter, perchloric acid $(5 \mathrm{~mL})$ was added for complete digestion. Digestion process was followed by cooling of the solution by adding $25 \mathrm{~mL}$ distilled water. The resultant solution was filtered through Whatman filter paper No. 1. Filtrate thus recovered was diluted to $100 \mathrm{~mL}$ by adding distilled water. $5 \mathrm{~mL}$ of filtrate was taken along with $5 \mathrm{~mL}$ of ammonium molybdate and $1.0 \mathrm{~mL}$ of distilled water added. Stannous chloride in glycerol (4-5 drops) was added and the final volume was maintained to $100 \mathrm{~mL}$. The resultant solution was allowed to stand for $10-15$ minutes. The absorbance of intense blue color developed after 15 minutes was recorded at $700 \mathrm{~nm}$. Total P content was calculated by using the following formula:

$$
\begin{aligned}
& \text { Total Phosphorus }\left(\frac{\mathrm{mg}}{\mathrm{Kg}}\right)=\frac{\mu \mathrm{g} \mathrm{P} \times 100}{\operatorname{Aliquat}(5 \mathrm{~mL}) \times \text { weight of soil }} \\
& \text { Total } \mathrm{P} \%=\frac{4 \mathrm{P} \times 100 \times 100}{\text { the sample in } \mathrm{mg} \times \text { aliquat }(5 \mathrm{~mL}) \times 1000}
\end{aligned}
$$


RASĀYAN J. Chem.

Vol. 12 | No. 2 |421 - 430| April - June | 2019

\section{Determination of Total Nitrogen (TN) by Kjeldahl Method (KEL PLUS Automatic Nitrogen Estimation System)}

For the estimation of TN in the soil, Kelplus Distyl- EMVA Kjeldahl apparatus was used. In this method, $3.5 \mathrm{~g}$ mixture of $\mathrm{CuSO}_{4}$ and $\mathrm{K}_{2} \mathrm{SO}_{4}$ in the ratio of 1:10 was added in $1.0 \mathrm{~g}$ of the soil sample. After that, 10 $\mathrm{mL}$ of concentrated $\mathrm{H}_{2} \mathrm{SO}_{4}$ was added and digested for 2 hours. After digestion, the solution was diluted with $40 \mathrm{~mL}$ distilled water. Apart from this, the distillation process was carried out in the distillation apparatus. During the distillation process, nitrogen was accumulated in the boric acid mixed indicator. The color changes from violet to green in the boric acid mixed indicator. This indicates the presence of $\mathrm{N}$ in the sample. Finally, distillate was titrated against $0.1 \mathrm{~N} \mathrm{H}_{2} \mathrm{SO}_{4}$ till the appearance of light blue color or violet color.

\section{Determination of K (Flame Photometer Method)}

$5 \mathrm{~g}$ of soil sample was taken in $250 \mathrm{~mL}$ flask. Added $25 \mathrm{~mL}$ of $1 \mathrm{~N}$ Ammonium acetate and shaken for 1 hour. The content was filtered using filter paper (Whatman no.1). K present in soil samples was further estimated using flame photometer (Systronics Model No. 2180).

\section{Biological Properties-Estimation of Enzymatic Activity in Soil Amylase $^{15}$}

$0.2 \mathrm{~mL}$ of toluene was added to $3 \mathrm{~g}$ of preserved soil sample $\left(4^{\circ} \mathrm{C}\right)$. The mixture was kept at room temperature for 15 minutes. Thereafter, $6 \mathrm{~mL}$ of Sorensen buffer and $6 \mathrm{~mL}$ of $1 \%$ starch solution were added to the flask. The mixture was incubated at $30^{\circ} \mathrm{C}$ for 24 hours. After the incubation period, the mixture was centrifuged at $10000 \mathrm{rpm}$ for 10 minutes. $1 \mathrm{~mL}$ of supernatant was taken out and $2 \mathrm{~mL}$ of 3 , 5 dinitrosalicylic acid solution was added. The solution was put in a water bath under boiling conditions to allow color development. After the development of a dark red color, the final volume was made to 5 $\mathrm{mL}$. Absorbance was recorded at $540 \mathrm{~nm}$ against the blank sample.

\section{Cellulase $^{16}$}

A soil sample $(1 \mathrm{~g})$ was dissolved in $0.1 \mathrm{~mL}$ of toluene. The mixture was kept at room temperature for 15 minutes. Sorensen buffer $(2 \mathrm{~mL})$ and substrate solution $(2 \mathrm{~mL})$ were added. The whole mixture was incubated at $30^{\circ} \mathrm{C}$ for 24 hours. Control was prepared in the same manner as the sample was prepared. All the contents were centrifuged at $4000 \mathrm{rpm}$ for 10 minutes. $1 \mathrm{~mL}$ of supernatant was pipetted out followed by the addition of 3,5- dinitrosalicylic acid. The solution was kept under boiling conditions in a water bath for color development. After the development of a dark red color, the final volume was made to 5 $\mathrm{mL}$. Absorbance was recorded at $540 \mathrm{~nm}$ against the blank.

\section{Invertase $^{17}$}

A soil sample $(1 \mathrm{~g})$ was dissolved in $0.1 \mathrm{~mL}$ of toluene. The mixture was kept at room temperature for 15 minutes. Sorensen buffer $(2 \mathrm{~mL})$ and substrate solution $(2 \mathrm{~mL})$ were added. The whole mixture was incubated at $30^{\circ} \mathrm{C}$ for 24 hours. Control was prepared in the same manner as the sample was prepared. All the contents were centrifuged at $4000 \mathrm{rpm}$ for 10 minutes. $1 \mathrm{~mL}$ of supernatant was pipetted out followed by the addition of 3,5-dinitrosalicylic acid. The solution was kept under boiling conditions in a water bath for color development. After the development of a dark red color, the final volume was made to 5 $\mathrm{mL}$. Absorbance was recorded at $540 \mathrm{~nm}$ against the blank. The enzymatic activities were calculated by plotting standard curves for all enzymes against a particular substrate. Glucose was used as a substrate for preparing standard curves of amylase, invertase and cellulase.

\section{Dehydrogenase}

Three percent (3\%) solution of 2, 3, 5-triphenyl tetrazolium chloride, $5 \mathrm{~g}$ of soil sample and distilled water $(2.5 \mathrm{~mL})$ were mixed together. The mixture was incubated for 1 day at $37^{\circ} \mathrm{C}$. Incubation of mixture was followed by addition of methanol $(10 \mathrm{~mL})$. The contents were shaken for 1 minute. The suspension was filtered through filter paper (Whatman No. 1). Extraction was further carried out with methanol till the disappearance of reddish color in the extract. The volume of the extract was raised to $50 \mathrm{~mL}$ with 
methanol. The absorbance of the mixture was measured at $485 \mathrm{~nm}$ with methanol as blank. 1, 3, 5triphenyl tetrazolium formazon was used for the preparation of a standard curve. The activity of dehydrogenase was expressed as $\mu \mathrm{gTPF} / \mathrm{g} / 24 \mathrm{~h}$.

\section{Statistical Analysis}

All the experiments were performed twice to confirm the validity of the results. Three replicates were maintained for each treatment.

\section{RESULTS AND DISCUSSION}

The impacts of biomass burning on soil were analyzed in terms of physicochemical, total organic matter, macronutrients and biochemical properties of soil in pre and post-burning periods. The post burning samples were collected within $72 \mathrm{~h}$ of the burning of rice crop residue.

\section{Impact of in situ Rice Crop Residue Burning on Soil pH and EC}

The $\mathrm{pH}$ analysis of the soil samples collected from the district Bathinda, indicates that the soils of the area are alkaline in nature. Further, the results of the analysis of soil samples collected during the pre and postburning period indicate an increase in soil $\mathrm{pH}$ after rice residue burning. In all the 10 samples from different villages, the $\mathrm{pH}$ of the soil samples collected post burning period was higher than the soil collected pre-burning period as detailed in Table-1. The soil $\mathrm{pH}$ of the samples during the pre-burning period ranged 7.32 to 8.41 and the same was 8.03 to 8.8 during post burning period (Table-3). The mean value for $\mathrm{pH}$ of soil samples of the pre-burning period was 7.94 and in post burning period, it increased significantly to 8.46 (Table-3).

Similar results were also observed in the case of EC. The EC of the soil samples collected in the post burning period was higher than the soil samples of the pre-burning period for all the sites (Table-1). The EC of soil samples before biomass burning ranged from $245-699 \mu \mathrm{S} / \mathrm{cm}$ which increased significantly from 403- $800 \mu \mathrm{S} / \mathrm{cm}$ (Table-3). The average increase in EC post burning was nearly 1.5 times as indicated by the mean value of EC of soil samples of pre-burning $(394.8 \mu \mathrm{S} / \mathrm{cm})$ and post-burning $(551.7$ $\mu \mathrm{S} / \mathrm{cm})($ Table-3).

\section{Impact of in situ Rice Crop Residue Burning on Soil Organic Matter (SOM) and Macronutrients Content}

SOM was higher in agricultural soils collected post residue burning. The mean value of OM in soil samples collected pre and post residue burning was 25200 and $27100 \mathrm{mg} / \mathrm{kg}$, respectively (Table-3). Individually, the increase in organic content in post residue burning was not significant for most of the sites (Table-2). Apart from SOM, the other important macronutrients required for plant growth are N, P and $\mathrm{K}$. Hence, the effect of in situ rice crop residue burning on these macronutrients was also determined. The in situ rice crop residue burning showed a decrease in total $\mathrm{N}$ and $\mathrm{P}$ content while the $\mathrm{K}$ content increased.

\begin{tabular}{c|c|c|c|c|c|c}
\multicolumn{2}{c}{ Table-1: $\mathrm{pH}$ and EC of soil samples collected pre and post in situ rice crop residue burning } \\
\hline \multirow{2}{*}{ Village Name } & \multicolumn{2}{|c|}{ Co-ordinates } & \multicolumn{2}{c|}{$\mathrm{pH}$} \\
Mean \pm S.E & \multicolumn{2}{c}{$\begin{array}{c}\text { EC }(\mu \mathrm{S} / \mathrm{cm}) \\
\text { Mean } \pm \text { S.E }\end{array}$} \\
\hline & $\begin{array}{c}\text { North } \\
\text { Latitude }\end{array}$ & $\begin{array}{c}\text { East } \\
\text { Longitude }\end{array}$ & Pre Burning & Post Burning & Pre Burning & Post Burning \\
\hline Gulabgarh & 30.143 & 74.988 & $8.27 \pm 0.043$ & $8.57 \pm 0.087$ & $699 \pm 10.13$ & $800 \pm 9.29$ \\
\hline Gehri bhagi & 30.115 & 74.96 & $7.83 \pm 0.033$ & $8.03 \pm 0.023$ & $383 \pm 4.93$ & $476 \pm 7.4$ \\
\hline Gehri butter & 30.096 & 74.877 & $7.98 \pm 0.45$ & $8.28 \pm 0.035$ & $526 \pm 10.1$ & $607 \pm 10.4$ \\
\hline Sangat & 30.082 & 74.941 & $7.32 \pm 0.04$ & $8.32 \pm 0.054$ & $392 \pm 8.65$ & $504 \pm 6.87$ \\
\hline $\begin{array}{c}\text { Katar Singh } \\
\text { wala }\end{array}$ & 30.168 & 74.994 & $8.41 \pm 0.063$ & $8.54 \pm 0.078$ & $355 \pm 3.45$ & $590 \pm 8.54$ \\
\hline Chak Ruldu & 30.186 & 75.123 & $7.97 \pm 0.029$ & $8.6 \pm 0.076$ & $281 \pm 3.20$ & $440 \pm 13.43$ \\
\hline Rama Mandi & 30.215 & 74.948 & $8.07 \pm 0.043$ & $8.47 \pm 0.095$ & $331 \pm 3.42$ & $541 \pm 7.9$ \\
\hline Mohalla & 30.071 & 74.755 & $7.86 \pm 0.05$ & $8.56 \pm 0.082$ & $346 \pm 4.12$ & $532 \pm 13.5$ \\
\hline
\end{tabular}


RASĀYAN J. Chem.

Vol. 12 | No. 2 |421 - 430| April - June | 2019

\begin{tabular}{c|c|c|c|c|c|c}
\hline Burj & 30.024 & 75.178 & $7.8 \pm 0.022$ & $8.8 \pm 0.065$ & $245 \pm 2.98$ & $803 \pm 18$ \\
\hline Menuana & 29.879 & 75.139 & $7.92 \pm 0.044$ & $8.42 \pm 0.08$ & $390 \pm 6.96$ & $624 \pm 15.4$ \\
\hline
\end{tabular}

Data are represented as mean \pm S.E (3 replicates)

Table-2: N, P, K and OM of soil samples collected pre and post in situ rice crop residue burning.

\begin{tabular}{|c|c|c|c|c|c|c|c|c|}
\hline \multirow[t]{2}{*}{$\begin{array}{l}\text { Village } \\
\text { Name }\end{array}$} & \multicolumn{2}{|c|}{$\begin{array}{c}\mathrm{OM}(\mathrm{mg} / \mathrm{kg}) \\
\text { Mean } \pm \text { S.E }\end{array}$} & \multicolumn{2}{|c|}{$\begin{array}{l}\mathrm{N}(\mathrm{mg} / \mathrm{kg}) \\
\text { Mean } \pm \mathrm{SE}\end{array}$} & \multicolumn{2}{|c|}{$\begin{array}{l}\mathrm{P}(\mathrm{mg} / \mathrm{kg}) \\
\text { Mean } \pm \text { S.E }\end{array}$} & \multicolumn{2}{|c|}{$\begin{array}{l}\mathrm{K}(\mathrm{mg} / \mathrm{kg}) \\
\text { Mean } \pm \text { S.E }\end{array}$} \\
\hline & $\begin{array}{c}\text { Pre } \\
\text { Burning }\end{array}$ & $\begin{array}{c}\text { Post } \\
\text { Burning }\end{array}$ & $\begin{array}{c}\text { Pre } \\
\text { Burning }\end{array}$ & $\begin{array}{c}\text { Post } \\
\text { Burning }\end{array}$ & $\begin{array}{c}\text { Pre } \\
\text { Burning }\end{array}$ & $\begin{array}{c}\text { Post } \\
\text { Burning }\end{array}$ & $\begin{array}{c}\text { Pre } \\
\text { Burning }\end{array}$ & $\begin{array}{c}\text { Post } \\
\text { Burning }\end{array}$ \\
\hline $\begin{array}{c}\text { Gulabgar } \\
\mathrm{h}\end{array}$ & $\begin{array}{c}29900 \pm \\
102\end{array}$ & $\begin{array}{c}29700 \pm 29 \\
2\end{array}$ & $\begin{array}{c}700 \pm 12 \\
5\end{array}$ & $\begin{array}{c}560 \pm 13 \\
6\end{array}$ & $510.4 \pm 12$ & $454.3 \pm 16$ & $\begin{array}{c}178.17 \pm 4.4 \\
4\end{array}$ & $\begin{array}{c}255.17 \pm 5.6 \\
5\end{array}$ \\
\hline $\begin{array}{l}\text { Gehri } \\
\text { bhagi }\end{array}$ & $\begin{array}{c}28900 \pm 16 \\
7 \\
\end{array}$ & $\begin{array}{c}30900 \pm 15 \\
3 \\
\end{array}$ & $\begin{array}{c}420 \pm 15 \\
4\end{array}$ & $370 \pm 15$ & $480.3 \pm 14$ & $415.7 \pm 7.6$ & $312.05 \pm 3.2$ & $\begin{array}{c}346.05 \pm 5.0 \\
5 \\
\end{array}$ \\
\hline $\begin{array}{l}\text { Gehri } \\
\text { butter }\end{array}$ & $\begin{array}{c}20700 \pm 30 \\
0 \\
\end{array}$ & $\begin{array}{c}21700 \pm 56 \\
4 \\
\end{array}$ & $\begin{array}{c}700 \pm 17 \\
7\end{array}$ & $\begin{array}{c}560 \pm 15 \\
6\end{array}$ & $\begin{array}{c}570.4 \pm 15 \\
4 \\
\end{array}$ & $\begin{array}{c}539.4 \pm 5.4 \\
3 \\
\end{array}$ & $\begin{array}{c}194.67 \pm 3.5 \\
4\end{array}$ & $\begin{array}{c}234.67 \pm 4.2 \\
3 \\
\end{array}$ \\
\hline Sangat & $\begin{array}{c}27900 \pm 43 \\
2 \\
\end{array}$ & $\begin{array}{c}28900 \pm 54 \\
0 \\
\end{array}$ & $\begin{array}{c}560 \pm 12 . \\
6 \\
\end{array}$ & $510 \pm 9.6$ & $\begin{array}{c}660.4 \pm 17 \\
5 \\
\end{array}$ & $\begin{array}{c}622.4 \pm 14 \\
6 \\
\end{array}$ & $\begin{array}{c}145.55 \pm 2.2 \\
2 \\
\end{array}$ & $225.55 \pm 5.5$ \\
\hline $\begin{array}{c}\text { Katar } \\
\text { Singh } \\
\text { wala }\end{array}$ & $\begin{array}{c}20900 \pm 54 \\
3\end{array}$ & $\begin{array}{c}23900 \pm 66 \\
5\end{array}$ & $580 \pm 16$ & $420 \pm 8.8$ & $\begin{array}{c}612.6 \pm 16 \\
7\end{array}$ & $\begin{array}{c}544.5 \pm 12 \\
5\end{array}$ & $73.66 \pm 2.56$ & $\begin{array}{c}193.66 \pm 4.3 \\
1\end{array}$ \\
\hline $\begin{array}{l}\text { Chak } \\
\text { Ruldu } \\
\end{array}$ & $\begin{array}{c}19500 \pm 40 \\
0 \\
\end{array}$ & $\begin{array}{c}23900 \pm 35 \\
8 \\
\end{array}$ & $550 \pm 9.6$ & $410 \pm 8.4$ & $\begin{array}{c}520.2 \pm 20 . \\
4\end{array}$ & $\begin{array}{c}601.8 \pm 11 \\
6\end{array}$ & $147.45 \pm 4.5$ & $\begin{array}{c}223.66 \pm 5.7 \\
4 \\
\end{array}$ \\
\hline $\begin{array}{l}\text { Rama } \\
\text { Mandi } \\
\end{array}$ & $\begin{array}{c}28300 \pm 32 \\
9 \\
\end{array}$ & $\begin{array}{c}29300 \pm 28 \\
8 \\
\end{array}$ & $\begin{array}{c}840 \pm 20 . \\
3 \\
\end{array}$ & $\begin{array}{c}700 \pm 10 . \\
3 \\
\end{array}$ & $\begin{array}{c}620.8 \pm 22 . \\
4 \\
\end{array}$ & $\begin{array}{c}552.2 \pm 14 \\
4 \\
\end{array}$ & $\begin{array}{c}142.97 \pm 3.1 \\
2 \\
\end{array}$ & $207.4 \pm 3.82$ \\
\hline Mohalla & $\begin{array}{c}28700 \pm 45 \\
2 \\
\end{array}$ & $\begin{array}{c}30700 \pm 39 \\
4 \\
\end{array}$ & $\begin{array}{c}730 \pm 14 \\
7\end{array}$ & $\begin{array}{c}560 \pm 15 \\
4\end{array}$ & $450.7 \pm 6.6$ & $\begin{array}{c}429.7 \pm 8.2 \\
3 \\
\end{array}$ & $\begin{array}{c}143.65 \pm 2.7 \\
6 \\
\end{array}$ & $234.6 \pm 3.43$ \\
\hline Burj & $\begin{array}{c}20300 \pm 54 \\
2 \\
\end{array}$ & $\begin{array}{c}23300 \pm 45 \\
3 \\
\end{array}$ & $\begin{array}{c}590 \pm 19 \\
4 \\
\end{array}$ & $\begin{array}{c}440 \pm 17 \\
3 \\
\end{array}$ & $\begin{array}{c}606.8 \pm 7.8 \\
8 \\
\end{array}$ & $\begin{array}{c}588.6 \pm 10 \\
3 \\
\end{array}$ & $\begin{array}{c}145.68 \pm 2.6 \\
5 \\
\end{array}$ & $254.8 \pm 4.34$ \\
\hline Menuana & $\begin{array}{c}26900 \pm 50 \\
5 \\
\end{array}$ & $\begin{array}{c}28900 \pm 46 \\
0 \\
\end{array}$ & $\begin{array}{c}850 \pm 11 \\
5 \\
\end{array}$ & $\begin{array}{c}700 \pm 14 \\
5 \\
\end{array}$ & $\begin{array}{c}840.4 \pm 21 . \\
5 \\
\end{array}$ & $\begin{array}{c}800.8 \pm 17 \\
8 \\
\end{array}$ & $\begin{array}{c}241.63 \pm 3.8 \\
7 \\
\end{array}$ & $298.5 \pm 4.02$ \\
\hline
\end{tabular}

Data is represented as mean \pm S.E (3 replicates).

The decrease in $\mathrm{N}$ and $\mathrm{P}$ was nearly consistent in all the samples collected (Table-2). The mean value of phosphorus in soil samples of pre and the post-burning period was $587 \mathrm{mg} / \mathrm{kg}$ and $554 \mathrm{mg} / \mathrm{kg}$, respectively. The mean $\%$ value of nitrogen, pre and post-burning was observed $0.06 \%$ and $0.05 \%$, respectively (Table-3 and Fig.-2). The potassium content is increased in agricultural soil after the biomass burning season. The mean value of $\mathrm{K}$ was $172.54 \mathrm{mg} / \mathrm{kg}$ and $247.3 \mathrm{mg} / \mathrm{kg}$ in pre and post biomass burning period (Table-3 and Fig.-2). The increase was also consistent in all the 10 samples collected from different sites (Table-2).

Table-3: Range and mean values of physicochemical properties of soil samples collected pre and post in situ rice crop residue burning

\begin{tabular}{c|c|c|c|c}
\hline & \multicolumn{2}{|c|}{ Pre-Burning } & \multicolumn{2}{c}{ Post Burning } \\
\hline Soil Parameter & Range & Mean \pm S.E & Range & Mean \pm S.E \\
\hline $\mathrm{pH}$ & $7.32-8.41$ & $7.94 \pm 0.29$ & $8.03-8.8$ & $8.46 \pm 0.21$ \\
\hline $\mathrm{EC}(\mu \mathrm{S} / \mathrm{cm})$ & $245-699$ & $394.8 \pm 130.53$ & $403-800$ & $551.7 \pm 112.79$ \\
\hline Nitrogen $(\mathrm{mg} / \mathrm{kg})$ & $420-850$ & $652(0.06 \%) \pm 136.2$ & $370-700$ & $523(0.05 \%) \pm 115.76$ \\
\hline Total P $(\mathrm{mg} / \mathrm{kg})$ & $450.7-840.4$ & $587.30 \pm 111.73$ & $415.7-800.8$ & $554.94 \pm 112.49$ \\
\hline $\mathrm{K}(\mathrm{mg} / \mathrm{kg})$ & $73.66-312.05$ & $172.54 \pm 65.25$ & $193.66-346.05$ & $247.41 \pm 45.11$ \\
\hline $\mathrm{OM}(\mathrm{mg} / \mathrm{kg})$ & $19500-29900$ & $25200 \pm 4256$ & $21700-30900$ & $27120 \pm 3489$ \\
\hline
\end{tabular}

Data are represented as mean \pm S.E (3 replicates).

Impact of Burning on Soil Enzymatic Activities

Soil enzymes play a key role in soil biochemical functions and microbiological activities. 
There is certain evidence suggesting that soil enzyme activity can be analyzed to be used as an indicator of microbial activity and soil fertility ${ }^{18}$. Soil enzymes respond quickly with a change in soil nutrient quality and act as good microbial indicators. Enzyme activities were tested and analyzed in this work. The results showed a significant decline in activities of all the studied enzymes for post burning soil samples while the enzymes isolated from pre-burning soil samples showed more activity (Table-4). The mean activity of amylase for the 10 samples decreased by approximately $25 \%$ while the decrease was nearly $50 \%$ or more for the cellulose, invertase and dehydrogenase (Fig.-3).

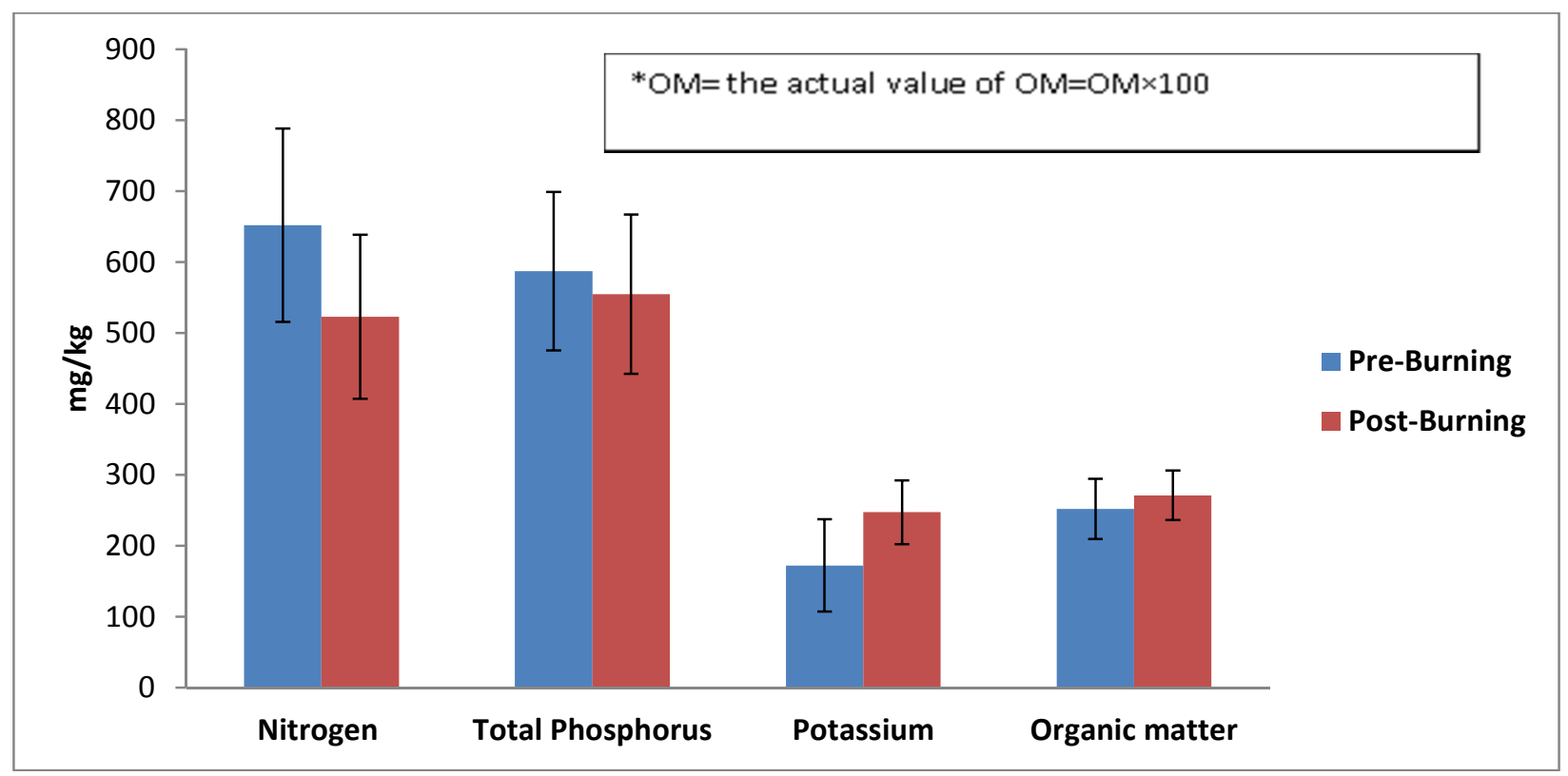

Fig.-2: Comparison of OM and N, P, K and OM of Soil Samples Collected Pre and Post in situ Rice Crop Residue Burning. Columns in the Graph represent Mean of N, P, K and OM for Pre and Post Burning Period (n=10) Whereas Error Bars represent Standard Deviation.

Table-4: Biochemical properties of soil samples collected pre and post in situ rice crop residue burning

\begin{tabular}{|c|c|c|c|c|c|c|c|c|}
\hline \multirow[t]{2}{*}{ Village Name } & \multicolumn{2}{|c|}{$\begin{array}{l}\text { Amylase }(\mu \mathrm{g} / \mathrm{g} / \mathrm{h}) \\
\text { Mean } \pm \text { S.E }\end{array}$} & \multicolumn{2}{|c|}{$\begin{array}{c}\text { Cellulase }(\mu \mathrm{g} / \mathrm{g} / \mathrm{h}) \\
\text { Mean } \pm \text { S.E }\end{array}$} & \multicolumn{2}{|c|}{$\begin{array}{c}\text { Invertase }(\mu \mathrm{g} / \mathrm{g} / \mathrm{h}) \\
\text { Mean } \pm \text { S.E }\end{array}$} & \multicolumn{2}{|c|}{$\begin{array}{c}\text { Dehydrogenase } \\
(\mu \mathrm{g} / \mathrm{g} / \mathrm{h}) \\
\text { Mean } \pm \text { S.E }\end{array}$} \\
\hline & $\begin{array}{c}\text { Pre } \\
\text { Burning }\end{array}$ & $\begin{array}{c}\text { Post } \\
\text { Burning }\end{array}$ & $\begin{array}{c}\text { Pre } \\
\text { Burning }\end{array}$ & $\begin{array}{c}\text { Post } \\
\text { Burning }\end{array}$ & $\begin{array}{c}\text { Pre } \\
\text { Burning }\end{array}$ & $\begin{array}{c}\text { Post } \\
\text { Burning }\end{array}$ & $\begin{array}{c}\text { Pre } \\
\text { Burning }\end{array}$ & $\begin{array}{c}\text { Post } \\
\text { Burning }\end{array}$ \\
\hline Gulabgarh & $123.28 \pm 2.2$ & $90.65 \pm 2.7$ & $93 \pm 3$ & $35 \pm 1.4$ & $289 \pm 5.4$ & $98 \pm 4.4$ & $21.4 \pm 1.23$ & $8.4 \pm 0.43$ \\
\hline Gehri bhagi & $109.13 \pm 4.5$ & $89.32 \pm 4.10$ & $102 \pm 2.5$ & $37 \pm 1.12$ & $261 \pm 5.9$ & $113 \pm 3.7$ & $55.8 \pm 2.98$ & $21.6 \pm 0.54$ \\
\hline Gehri butter & $86.49 \pm 4.6$ & $69.79 \pm 2.89$ & $72 \pm 2.9$ & $33 \pm 1.56$ & $255 \pm 4.6$ & $121 \pm 5$ & $33.8 \pm 3.2$ & $19.4 \pm 0.89$ \\
\hline Sangat & $101.21 \pm 5.7$ & $72.44 \pm 2.35$ & $96 \pm 3$ & $35 \pm 0.98$ & $293 \pm 8.4$ & $100 \pm 3.4$ & $16 \pm 0.94$ & $6.4 \pm 0.88$ \\
\hline $\begin{array}{c}\text { Katar Singh } \\
\text { wala } \\
\end{array}$ & $76.31 \pm 4.3$ & $61.97 \pm 1.90$ & $82 \pm 1.98$ & $30 \pm 0.76$ & $193 \pm 7.4$ & $85 \pm 3.8$ & $70.6 \pm 4.3$ & $29.6 \pm 1.34$ \\
\hline Chak Ruldu & $107.53 \pm 3.2$ & $81.49 \pm 2$ & $97 \pm 4.3$ & $45 \pm 1.4$ & $273 \pm 7$ & $223 \pm 7.54$ & $86.6 \pm 3.67$ & $54.8 \pm 2.55$ \\
\hline Rama Mandi & $124.89 \pm 7.4$ & $97.81 \pm 1.68$ & $60 \pm 3.76$ & $43 \pm 0.77$ & $168 \pm 5.5$ & $105 \pm 4$ & $15.8 \pm 0.34$ & $2.4 \pm 0.12$ \\
\hline Mohalla & $78.38 \pm 5.4$ & $54.89 \pm 1.32$ & $119 \pm 3.12$ & $45 \pm 0.89$ & $239 \pm 4.9$ & $102 \pm 3.23$ & $39.6 \pm 0.44$ & $9.6 \pm 0.45$ \\
\hline Burj & $90.46 \pm 23$ & $45.44 \pm 0.89$ & $93 \pm 2.83$ & $68 \pm 1.30$ & $177 \pm 5.4$ & $60 \pm 2.98$ & $12.6 \pm 0.65$ & $4.8 \pm 0.54$ \\
\hline Menuana & $129.22 \pm 3.3$ & $74.04 \pm 2.5$ & $133 \pm 4.45$ & $77 \pm 1.87$ & $259 \pm 7.9$ & $152 \pm 4.2$ & $80.8 \pm 2.87$ & $35 \pm 1.23$ \\
\hline
\end{tabular}

Data are represented as mean \pm S.E (3 replicates).

The results show that the $\mathrm{pH} \& \mathrm{EC}$ increased in soil samples collected post burning period than a preburning period. The enhancement of $\mathrm{pH}$ is due to the presence of ash in soil ${ }^{19,20}$. The production and accumulation of ash may increase the $\mathrm{pH}$ of the soil. It may also be due to the formation of oxides, 
hydroxides and carbonates of sodium and potassium in surface soils ${ }^{21}$. The possible reason for an increase in electrical conductivity was the collapsing of aggregates and clogging of voids by the ash and dispersed ions $^{22,23}$.

SOM represents the largest terrestrial carbon pool $^{24}$ and is the main component of soil ecosystem that provides a protective cover to soil and regulates its temperature. It also provides habitat and substrates for soil flora and fauna ${ }^{25}$. In this study, the SOM of soil samples collected post in situ burning period was higher. It may be due to the increase of carbon mineralization process during the burning of rice straw ${ }^{26}$. The process of carbon mineralization depends on the intensity and temperature of burning. During highintensity burning, the temperature reaches $450^{\circ} \mathrm{C}$, whereas in moderate and low intensity burning temperature reaches $350^{\circ} \mathrm{C}$ and $250^{\circ} \mathrm{C}$, respectively ${ }^{25}$. The burning severity of straw of sampling sites is in medium severity and generally, the carbon content of soils increase after medium-severity fires ${ }^{27}$. The impact of biomass burning on SOM is also dependent on soil type, soil moisture and the nature of the burning materials.

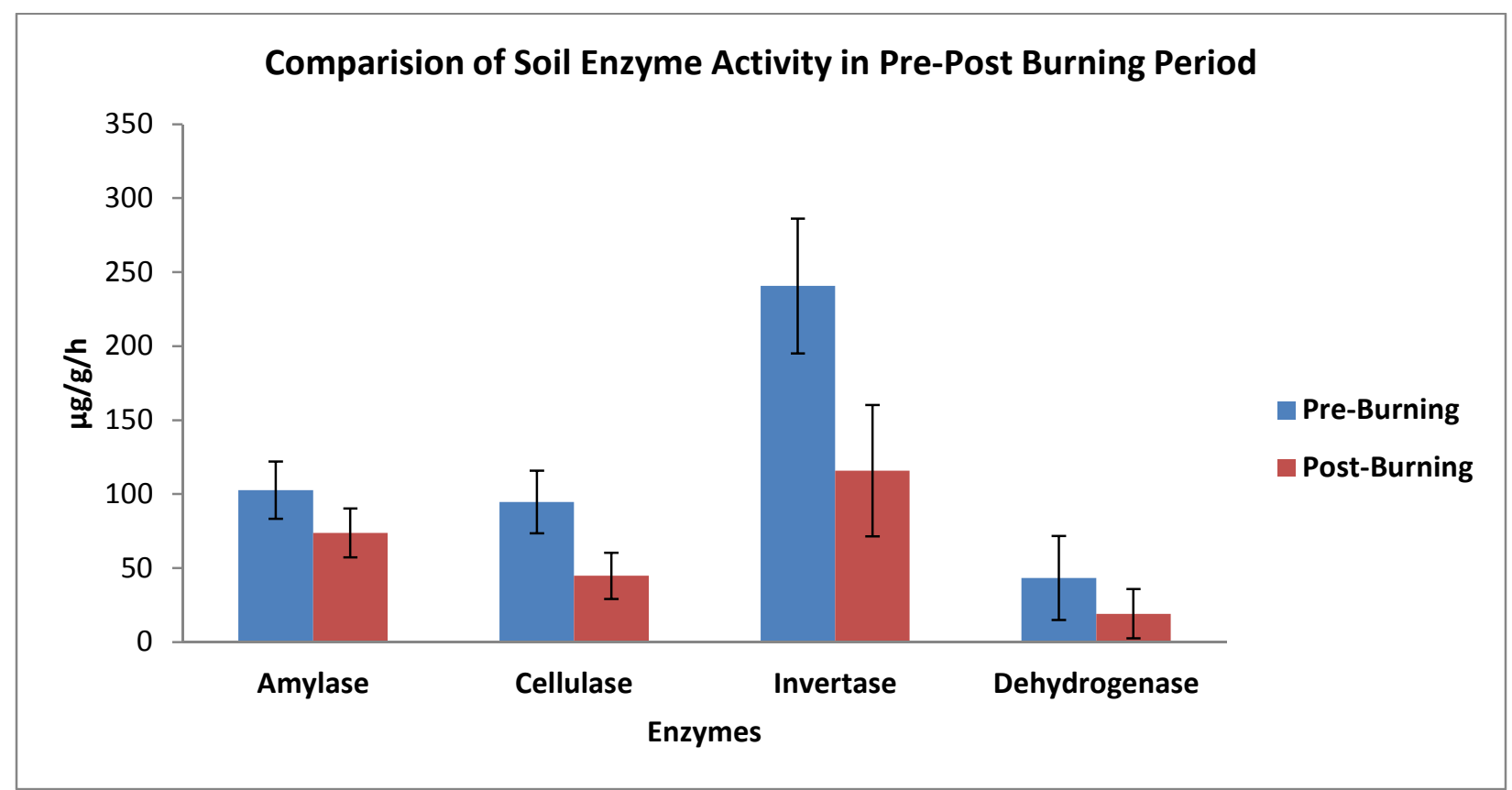

Fig.-3: Soil Enzyme Activities Pre and Post in situ Rice Crop Residue Burning. Columns in the Graph represent Mean of Amylase, Cellulase, Invertase and Dehydrogenase Activity for Pre and Post Burning Period $(n=10)$ Whereas Error Bars represent Standard Deviation.

Crop residue burning affects the availability of macro and micro nutrients in the soil. The macro and micro nutrients have an influence on crop productivity and vegetation dynamics ${ }^{28}$. N \& $\mathrm{P}$ are the important macronutrients of any agricultural system and their reduction affects soil fertility. The $\mathrm{N}$ and $\mathrm{P}$ content of soil samples collected post crop residue burning period was lower than soils collected preburning period. On the immediate effect, the volatilization process during the burning of agricultural biomass is the reason for the decrease of soil $\mathrm{N}$ and $\mathrm{P}$ content ${ }^{23,}{ }^{25,}{ }^{29}$. At $300^{\circ} \mathrm{C}$, half of the $\mathrm{N}$ in organic matter can be volatilized ${ }^{25,30}$. The $\mathrm{K}$ content was higher ${ }^{31}$ in soil samples collected post burning period compared to pre-burning period. $\mathrm{K}$ is the main indicator of crop residue burning ${ }^{32}$. This may be due to leaching of extractable $\mathrm{K}$ and mineralization of cations from burnt crop residue ${ }^{33}$.

Study of soil enzymatic activities is very helpful to understand the basic biochemical processes and soil fertility of any soil ${ }^{34}$. Amylase is a starch hydrolyzing enzyme and is constituted by $\alpha$ - and $\beta$-amylase. The activity of this enzyme may be influenced by certain factors such as vegetation type, environment and soil types. Amylase enzyme activities of soil may be influenced by the plants directly by supplying enzymes from their residues or indirectly providing substrates for the synthetic activities of microorganisms ${ }^{35}$. Cellulases are those enzymes that degrade cellulose in plant debris into glucose, cellobiose 
and oligosaccharides having high molecular weight. Invertase enzyme utilizes sucrose as a substrate and converts it into glucose and fructose. In general, increased organic matter (OM) content of the soil is an energy source for microbes ${ }^{36}$. But, here the results showed a decrease in enzyme activity in the soil after biomass burning despite an increase in OM. Here, the decrease in enzyme activity is due to 2 reasons: 1 ) the source of these enzymes are soil microbes, worms and insects. The in situ crop residue burning leads to the killing of these organisms and hence production of these enzymes. 2) Moreover, hydrolytic enzymes are deactivated due to high temperature during burning, thereby reducing soil enzymes activity $^{37}$. The biological activity of the soils is strongly indicated by the presence of dehydrogenase enzyme $^{38}$. This enzyme is responsible for the oxidation of organic matter present in the soil by transfer of electrons and protons. Dehydrogenase enzyme activities give an indication of soil potential to hold up biochemical processes that are vital to maintaining soil health and fertility. These results showed an alteration in the dehydrogenase activity of unburnt and burnt soil samples. The results are supported by the previous findings reporting that temperature affected dehydrogenase activity indirectly by influencing the redox status of soil ${ }^{39}$. The redox transformations are associated with the respiration activity of soil micro-organisms. The depressed soil enzyme activity was a clear indication that biomass burning changes the quality and quantity of substrates for microbes.

\section{CONCLUSION}

In situ crop residue burning significantly influences the physicochemical and biochemical properties of the soil. The burning leads to the loss of the two most important micronutrients $\mathrm{N}$ and $\mathrm{P}$. The losses of micronutrients increase fertilizers requirement for the next crop and add to the financial burden of the farmers. An increase in soil $\mathrm{pH}$ and electrical conductivity is attributed to the presence of ash in soil and clogging of voids by the ash and dispersed ions. This also negatively affects agriculture. The results also revealed a decrease in activities of soil enzymes like amylase, cellulase, invertase and dehydrogenase in post burning period. This indicates the decrease of soil microbes and soil friendly insects and worms and in-turn soil health. In the end, we conclude that the in situ crop residue is a harmful practice for agriculture soil and the farmers. Alternate methods need to be developed for management of the crop residues instead of its burning.

\section{ACKNOWLEDGMENT}

The authors are thankful to Giani Zail Singh Campus College of Engineering \& Technology, Bathinda151001, Punjab, India, for providing infrastructure for research work. I am also thankful to UGC, New Delhi for providing the Junior Research Fellowship.

\section{REFERENCES}

1. M. Butnariu, Journal of Ecosystem and Ecography., 2, 1(2012), DOI: 10.4172/2157$7625.1000 \mathrm{e} 103$

2. J. Pietiikainen, and H. Fritze, Soil Biology and Biochemistry, 27(1), 101(1995), DOI: 10.1016/0038-0717(94)00125-K

3. C. Chandler, P. Cheney, P. Thomas, L. Trabaud, and D. Williams, Fire in Forestry, Vol. I, Forest fire behavior and effects, Vol. II, Wiley, New York (1983).

4. D. Grover, P. Kaur, and H. R. Sharma, Environment and We an International Journal of Science and Technology, 10,75(2015).

5. M. S. Bishnoi, P. Malik, S. Ram, S., and A. Chandra, Environment and We an International Journal of Science and Technology, 6, 175(2011).

6. J. A. Amador, A. M. Glucksman, J. B. Lyons, and J. H. Gorres, Soil Science, 162(11), 808(1997), DOI: $10.1097 / 00010694-199711000-00005$

7. M. A. Tabatabai, 1994. Soil enzymes, in: A. L. Page, R. H. Miller, D. R. Keeney (Eds.), Methods of soil analysis. American Society of Agronomy, Madison, pp. 775-833.

8. S. Kiss, M. Dragan-Bularda, and D. Radulescu, 1978, Soil polysaccharidases: activity and agricultural importance, in: R. G. Burns (Ed), Soil enzymes, Academic, London, pp. 117-147.

9. V. V. S. R. Gupta, R. E. Farrell, and J. J. Germida, Canadian Journal of Soil Science,73, 341 (1993), DOI: $10.4141 /$ cjss93-036 
RASĀYAN J. Chem.

Vol. 12 | No. 2 |421 - 430| April - June | 2019

10. T. W. Speir, New Zealand Journal of Science, 20, 159(1977).

11. Indian Standard (1987). Methods of test for soils (Second revision). Determination of pH value. IS: 2720 (Part 26) -1987

12. Indian Standard (2000), Determination of the Specific Electrical Conductivity of Soils- Method of Test, IS: $14767-2000$.

13. A. Walkley, Soil Science, 63, 251(1947), DOI: 10.1097/00010694-194704000-00001

14. M. L. Jackson, Soil Chemical Analysis, Prentice-Hall of India, New Delhi, pp. 134(1973).

15. S. P. Deng, and M. A. Tabatabai, Soil Biology and Biochemistry, 26(10), 1347(1994), DOI: 10.1016/0038-0717(94)90216-X

16. C. M. Tu, Chemosphere, 17(1), 159(1988), DOI: 10.1016/0045-6535(88)90053-7

17. N. N. Y. Badiane, J. L. Chotte, E. Pate, D. Masse, and C. Rouland, Applied Soil Ecology, 18(3), 229(2001), DOI: 10.1016/S0929-1393(01)00159-7

18. D. J. Ross, New Zealand Journal of Science, 18, 511(1975), DOI: 10.1016/0038-0717(83)90073-1

19. M. Molina, R. Fuentes, R. Calderon, M. Escudey, K. Avendano, M. Gutierrez, and A. C. Chang, Soil Science, 172, 820(2007), DOI: 10.1097/ss.0b013e31814cee44

20. J. L. Schafer, and M. C. Mack, Plant and soil, 334, 433(2010), DOI: 10.1007/s11104-010-0394-2

21. A. L. Ulery, R. C. Graham, and C. Amrhein, Soil Science, 156, 358(1993), DOI: 10.1097/00010694-199311000-00008

22. R. E. J. Boerner, J. Huang, and S. C. Hart, Ecological Applications, 19,338(2009), DOI: 10.1890/07-1767.1

23. G. Certini, Oecologia, 143, 1(2005), DOI: 10.1007/s00442-004-1788-8

24. R. Lal, European Journal of Soil Science, 60, 158(2009), DOI: 10.1111/j.1365-2389.2008.01114.x.

25. D. G. Neary, C. C. Klopatek, L. F. DeBano, and P. F. Folliott, Forest ecology and management, 122, 51(1999), DOI: 10.1016/S0378-1127(99)00032-8.

26. M. I. Bird, C. Moyo, E. M. Veenendaal, J. Lloyd, and P. Frost, Global Biogeochemical Cycles,13, 923(1999), DOI: $10.1029 / 1999$ GB900067.

27. J. A. Gonzalez-Perez, F. J. Gonzalez-Vila, G. Almendros, H. Knicker, Environment international, 30(6), 855(2004), DOI: 10.1016/j.envint.2004.02.003

28. R. P. Ganorkar, H. A. Hole, and D. A. Pund, Rasayan Journal of Chemistry, 10(2), 429(2017), DOI: $10.7324 /$ RJC.2017.1021665.

29. T. G. Caldwell, D. W. Johnson, W. W. Miller, and R. G. Qualls, Soil Science Society of America Journal, 66(1), 262(2002), DOI: 10.2136/sssaj2002.2620

30. H. Knicker, Biogeochemistry, 85, 91(2007), DOI: 10.1007/s10533-007-9104-4

31. J. C. Neff, J. W. Harden, and G. Gleixner, Canadian Journal of Forest Research, 35(9), 2178(2005), DOI: 10.1139/x05-154

32. N. Singh, S. Mittal, R. Singh, R. Agarwal, A. Awasthi, and P. K.Gupta, Chemistry Review, 1(2), 47(2013), DOI: $10.15415 /$ ccr.2013.12010

33. U. E. Chaudhari, and P. S. Jichkar, Rasayan Journal of Chemistry, 5(2), 142(2012).

34. L. Sripathy, P. Rao, N. M. Ajay Kumar, S. Yashwanth, Jagadisha, N. Divya, and K. R. Sharada, Rasayan Journal of Chemistry, 8(2), 232(2015).

35. K. Wallenius, H. Rita, A. Mikkonen, K. Lappi, K. Lindstrom, H. Hartikainen, A. Raateland, and R. M. Niemi, Soil Biology and Biochemistry, 43(7), 1464(2011), DOI: 10.1016/j.soilbio.2011.03.018

36. R. E. J. Boerner, J. A. Brinkman, and A. Smith, Soil Biology and Biochemistry, 37(8), 1419(2005), DOI: $10.1016 /$ j.soilbio.2004.12.012

37. S. B. Singh, S. Saha, S. K. Dutta, A. R. Singh, and T. Boopathi, CATENA, 156, 10(2017), DOI: 10.1016/j.catena.2017.03.017

38. R. G. Burns, 1978, Enzyme activity in soil: some theoretical and practical considerations, in: R. G. Bums (Ed), Soil enzymes, Academic, London, pp 295-340.

39. M. Brzezinska, Z. Stepniewska, and W. Stepniewski, Soil Biology and Biochemistry, 30, 1783(1998), DOI: 10.1016/S0038-0717(98)00043-1

[RJC-5160/2019] 